\title{
Hubungan antara Detraining Selama Pandemi Covid-19 dengan Kemampuan Daya Ledak Otot Tungkai Atlet UKM Karate
}

\author{
Fitria Ningsih*, Olivia Andiana, Ahmad Abdullah \\ Universitas Negeri Malang, Jl. Semarang No. 5 Malang, Jawa Timur, Indonesia \\ *Penulis korespondensi, Surel: fitria171n@gmail.com
}

Paper received: 1-10-2021; revised: 19-10-2021; accepted: 25-10-2021

\begin{abstract}
Karate is one of the most popular martial arts practiced around the world. Karate training puts a great deal of stress on the peripheral joints, and the rotational motion of the spine can greatly affect their mobility. Explosive power is needed in the sport of karate because explosive power is a support in every karate technique movement. Someone who stops exercising for 2-4 weeks will experience a decrease in physiological functions of the body or can be called detraining. The purpose of this study was to determine whether there was a relationship between detraining during the Covid-19 pandemic against the leg muscle explosive power of athletes of Karate UKM State University of Malang. The research is a quantitative correlational study with a causal design. In this research, the sample used is athlete karate State University of Malang as many as 19 people. The data collection method used According to the research, there is a relationship between detraining explosive muscle leg athletes ukm karate Universitas Malang with a p-value is 0.000 less than $\alpha$ is 0,05 and Value correlation coefficient obtained by 0.886 . Research concludes that there is a relationship between detraining during the Covid - 19 pandemic on the leg muscle explosive power of SMK karate athletes, State University of Malang.
\end{abstract}

Keywords: detraining; limb muscle explosive power; karate

\begin{abstract}
Abstrak
Karate merupakan salah satu beladiri yang paling populer dipraktikkan di seluruh dunia. Pelatihan karate memberikan tekanan yang besar pada sendi perifer, dan gerakan rotasi tulang belakang dapat sangat mempengaruhi mobilitasnya. Daya ledak sangat dibutuhkan dalam olahraga karate dikarenakan daya ledak merupakan penunjang dalam setiap gerakan teknik karate. Seseorang yang berhenti latihan selama 2-4 minggu akan mengalami penurunan fungsi fisiologis terhadap tubuh atau bisa disebut detraining. Tujuan dari penelitian ini adalah untuk mengetahui apakah terdapat hubungan antara detraining selama pandemic Covid-19 terhadap daya ledak otot tungkai Atlet UKM Karate Universitas Negeri Malang. Penelitian ini merupakan penelitian kuantitatif korelasional dengan desain sebab akibat. Dalam penelitian ini, sampel yang digunakan merupakan atlet karate Universitas Negeri Malang sebanyak 19 orang. Metode pengambilan data menggunakan Berdasarkan hasil penelitian, terdapat hubungan antara detraining dengan daya ledak otot tungkai atlet ukm karate Universitas Negeri Malang dengan $p$-value sama dengan 0,000 kurang dari $\alpha$ sama dengan 0,05 dan Nilai correlation coefficient yang didapatkan sebesar 0,886 . Penelitian ini menyimpulkan bahwa terdapat hubungan antara detraining selama pandemic Covid- 19 terhadap daya ledak otot tungkai atlet ukm karate Universitas Negeri Malang.
\end{abstract}

Kata kunci: detraining; daya ledak otot tungkai; karate

\section{Pendahuluan}

Di awal tahun 2020, dunia dihebohkan dengan munculnya virus baru yaitu Covid-19. Kasus Covid-19 meningkat setiap hari, dan penyebaran virus akan dimulai di Wuhan, dataran di Cina. Dalam waktu kurang dari sebulan, virus tersebut menyebar ke China, termasuk 
Indonesia, Thailand, Jepang, dan Korea Selatan. Di Indonesia, 306 orang meninggal dalam setiap bulannya (Zhenga, 2020: 23).

Maka, di awal pandemi Covid-19, pemerintah telah memberlakukan banyak pembatasan untuk mencegah penyebaran Covid-19, dimulai dengan kebijakan PSBB, dari rumah saja, WFH dan selalu menggunakan masker dan hand sanitizer. Setiap kebijakan memberikan pengaruhnya sendiri. Salah satu dampak dari Covid-19 adalah perubahan gaya hidup. Misalnya, perubahan gaya hidup dapat berdampak buruk pada kurangnya aktivitas fisik dan perilaku diet dan organisme (Matioli 2020:852).

Waktu istirahat yang terlalu lama akan menyebabkan seseorang merasa kelelahan, dan fungsi fisiologis tubuh akan berkurang atau menurun. Kurangnya latihan fisik, pola makan yang tidak seimbang, dan perubahan gaya hidup juga merupakan faktor yang berkontribusi terhadap penyebab detraining (Ploughman dan Smith, 2014). Secara keseluruhan, Detraining akan terjadi pada sistem neuromuskular, metabolisme, dan otonom cardiopulmonary, yang dapat mempengaruhi semua komponen kebugaran, termasuk kekuatan otot, kecepatan, keseimbangan, koordinasi, fleksibilitas, dan daya tahan kardiovaskular (Lennon, 2018: 487).

Penurunan adaptasi fisiologis dapat menyebabkan penurunan massa otot sehingga akan berdampak pada penurunan kekuatan, power dan performa pada atlet cabang olahraga karate. Menurut Kusmiranti (2019: 5354), ada hubungan antara kekuatan kaki dengan hasil tendangan karate Mawashigeri dan Ushirogeri. Hal ini menunjukkan bahwa kekuatan kaki merupakan faktor penting saat menendang dalam olahraga karate. Hal ini menggambarkan bahwa power tungkai merupakan faktor penting untuk menghasilkan tendangan. Maka dari itu power sangat dibutuhkan dalam cabang olahraga karate.

Tujuan dari penelitian ini adalah untuk mengetahui apakah terdapat hubungan antara detraining selama pandemi Covid-19 terhadap daya ledak otot tungkai Atlet Ukm Karate Universitas Negeri Malang. Manfaat dalam penelitian ini digunakan sebagai salah satu upaya untuk mengetahui hubungan antara detraining terhadap daya ledak otot tungkai atlet UKM karate Universitas Negeri Malang.

\section{Metode}

Penelitian ini merupakan penelitian kuantitatif korelasional dengan desain sebab akibat (Maksum, 2009). Metode penelitian kuantitatif adalah penelitian yang sifatnya formal, sistematis, obyektif, menguji hubungan, dan menguji interaksi antara penyebab dan akibat antara masing-masing variabel penelitian (Swarjana, 2016). Metode pengambilan data dilakukan dengan metode survey.

Penelitian ini dilaksanakan di Lapangan Tenis Universitas Negeri Malang pada bulan november 2020 yang berlokasi Universitas Negeri Malang, dengan jumlah populasi yang diambil sebanyak 25 orang dan yang memenuhi kriteria sebanyak 19 orang atlet UKM karate.

Teknik pengumpulan data variable dertaining yang dilakukan dalam penelitian ini adalah survey atau wawancara terhadap responden selanjutnya untuk variable daya ledak otot tungkai mengunakan tes vertical jump dengan tahapan yang diawali melengkapi biodata testi atau Informent Consent yang di berikan peneliti selanjutnya memberikan pemanasan kepada testi untuk mengurangi resiko cedera saat melakukan tes yaitu vertical jump. Data yang sudah di ambil akan dianalisis mengunakan SPSS 25.0. 


\section{Hasil dan Pembahasan}

Berdasarkan hasil penelitian, data yang diperoleh dari wawancara atlet UKM karate universitas negeri malang, sebanyak 19 orang atlet sudah mengisi tes wawancara yang sudah disediakan melalui google form.

Tabel 1. Gambaran Karakteristik Responden

\begin{tabular}{clcl}
\hline No & Fakultas & Jumlah (N=19) & Presentase \\
\hline 1 & FE & 2 & $10.52 \%$ \\
2 & FIK & 10 & $52,64 \%$ \\
3 & FIS & 2 & $10,52 \%$ \\
4 & PPSi & 2 & $10,52 \%$ \\
5 & FT & 2 & $10,52 \%$ \\
6 & FIP & 1 & $5,28 \%$ \\
Jumlah & & 19 & $100 \%$ \\
\hline
\end{tabular}

Jumlah responden yang paling banyak berada pada FIK dengan jumlah persentase sebesar $(52,64 \%)$ dengan jumlah atlet sebanyak 10 orang. sementara jumlah responden yang paling rendah pada FIP dengan jumlah persentase sebesar $(5,28 \%)$ dengan jumlah atlet sebanyak 1 orang.

Berdasarkan hasil penelitian didapatkan data sebagai berikut

\subsection{Kategori Detraining}

Tabel 2. Gambaran Karakteristik Responden Detraining

\begin{tabular}{clcc}
\hline No & Kategori Detraining & Jumlah & Presentase \\
\hline 1. & Sangat Rendah & - & - \\
2. & Rendah & 3 & $15,79 \%$ \\
3. & Normal & 5 & $26,32 \%$ \\
4. & Tinggi & 9 & $47,37 \%$ \\
5. & Sangat Tinggi & 2 & $10,53 \%$ \\
Total & & 19 & $100 \%$ \\
\hline
\end{tabular}

Dari hasil yang didapatkan responden detraining paling tinggi yaitu pada kategori tinggi dengan persentase sebesar $(47,37 \%)$ dan persentase paling rendah pada kategori rendah dengan jumlah persentase sebesar (15,73\%).

\subsection{Kategori Daya Ledak Otot Tungkai (Vertical Jump)}

Tabel 3. Gambaran Karakteristik Responden Daya Ledak otot tungkai (Vertical Jump)

\begin{tabular}{clcc}
\hline No & Kategori Detraining & Jumlah & Presentase \\
\hline 1. & Sangat Baik & - & - \\
2. & Baik & 2 & $10,52 \%$ \\
3. & Normal & 8 & $42,10 \%$ \\
4. & Kurang & 7 & $36,84 \%$ \\
5. & Sangat Kurang & 2 & $10,52 \%$ \\
Total & & 19 & $100 \%$ \\
\hline
\end{tabular}


Berdasarkan tabel diatas hasil yang didapat, persentase paling tinggi yaitu pada kategori sangat kurang dengan jumlah persentase sebesar $(42,10 \%)$ dan persentase paling rendah pada kategori baik dan normal dengan jumlah persentase sebesar (10,52\%).

\subsection{Analisis Data Menggunakan SPSS 25.0}

Tabel 4. Hasil Analisis Detraining Terhadap Daya Ledak

\begin{tabular}{|c|c|c|c|c|c|c|c|c|}
\hline \multirow{3}{*}{ Detraining } & \multicolumn{7}{|c|}{ Explosive Power } & \multirow{2}{*}{$\begin{array}{c}\text { Correlation } \\
\text { Coefficient }\end{array}$} \\
\hline & Baik Sekali & Baik & Coefficient & Kurang & Kurang Sekali & Jumlah & P-Value & \\
\hline & $\mathbf{N}$ & $\mathbf{N}$ & $\mathbf{N}$ & $\mathbf{N}$ & $\mathbf{N}$ & & & \\
\hline $\begin{array}{l}\text { Sangat } \\
\text { Rendah }\end{array}$ & & & & 1 & 1 & 2 & 0,00 & 0,886 \\
\hline Rendah & & & 2 & 1 & & 3 & & \\
\hline Normal & & & 2 & 2 & 1 & 5 & & \\
\hline Tinggi & & 2 & 4 & 3 & & 9 & & \\
\hline Sangat & & & & & & 0 & & \\
\hline $\begin{array}{l}\text { Tinggi } \\
\text { Jumlah }\end{array}$ & 0 & 2 & 8 & 7 & 2 & 19 & & \\
\hline
\end{tabular}

Hasil uji spearmen di dapatkan $p$-value $=0,000<\alpha=0,05$, dan correlations coefisient sebesar 0,886 yang berarti terdapat hubungan antara detraining selama masa pandemic covid - 19 terhadap daya ledak otot tungkai pada Atlet UKM Karate universitas Negeri Malang.

\subsection{Hubungan Detraining dan Daya Ledak}

Unsur-unsur kebugaran yang mendukung keterampilan teknis dan taktis karate meliputi daya tahan anaerobik, kelincahan, kekuatan, fleksibilitas dan kecepatan. Kondisi fisik dianggap menjadi landasan atlet, karena tanpa didukung kondisi fisik yang prima, sulit untuk mencapai hasil yang maksimal. Prasyarat fisik ini sangat diperlukan untuk menyerang dan bertahan.

Detraining adalah fenomena dimana kemampuan adaptasi fisiologis tubuh menurun atau hilang karena berhenti dan istirahat yang relatif lama. (Indrayana, 2019) mengatakan bahwa detraining adalah suatu keadaan dimana manfaat dari olahraga itu hilang, ini secara kolektif dikenal sebagai Kondisi fisik yang bisa dikatakan bukan lagi kualitas terbaik dan kualitas fisiknya semakin buruk.

Hasil uji spearman di dapatkan $p$-value $=0,000<\alpha=0,05$, yang berarti terdapat hubungan yang signifikan antara detraining dengan daya ledak otot. Dari hasil yang didapatkan menunjukkan bahwa semakin tinggi kejadian Detraining maka semakin menurunkan tingkat daya ledak seseorang. Correlation coefficient dari hasil tersebut menunjukkan arah hubungan yang positif $(+)$ yang berarti semakin tinggi tingkat Detraining maka akan terjadi penurunan yang signifikan terhadap daya ledak otot tungkai Atlet UKM Karate UM. Nilai correlation coefficient yang didapatkan sebesar 0,886 dan diinterpretasikan dengan kekuatan hubungan pada tingkat sangat kuat. Terdapat 8 responden yang mengalami detraining tingkat tinggi mengakibatkan penurunan daya ledak otot tungkai pada tingkat kurang sekali. Berdasarkan hasil tersebut dapat dikatakan bahwa semakin tinggi tingkat Detraining maka akan terjadi penurunan yang signifikan terhadap daya ledak otot tungkai Atlet UKM Karate UM. 
Pembahasan di atas menunjukkan bahwa tingkat latihan erat kaitannya dengan tingkat daya ledak seseorang. Semakin tinggi tingkat detraining, semakin rendah daya ledak seseorang. Dari hasil penelitian tersebut selaras dengan teori-teori yang telah dikemukakan oleh para ahli sebelumnya, yang menjelaskan bahwa detraining dapat terjadi di Sistem saraf otonom, metabolisme, dan kardiopulmoner secara otomatis mempengaruhi semua komponen kebugaran, termasuk otot, kecepatan dan kekuatan, keseimbangan, koordinasi, fleksibilitas, dan daya tahan kardiovaskular (Lennon et al., 2018). selain itu (joo, 2018) menjelaskan bahwa waktu istirahat atau gangguan latihan yang lebih lama dapat berdampak negatif pada aktivitas fisik. Kondisi fisik, terutama kebugaran jasmani, dapat menyebabkan hilangnya adaptasi fisiologis dan fungsi tubuh. Daya Ledak otot tergantung pada dua faktor, yaitu kekuatan dan kecepatan. Kekuatan adalah pondasinya. Atas dasar ini, kekuatan merupakan unsur utama untuk menghasilkan power dan daya tahan otot. (Satria, 2017). Menurut Tran (2016), ia mengatakan bahwa penelitiannya menunjukkan bahwa penghentian latihan secara teratur selama empat minggu dapat secara signifikan mengurangi ketinggian lompat vertikal sebesar $5,26 \%$.

Dari hasil penelitian menurut beberapa ahli di atas dapat disimpulkan bahwa power tidak akan maksimal jika tidak di dukung oleh dua faktor yaitu kekuatan dan kecepatan. Pemberhentian atau penggantian program latihan akan berdampak terhadap perubahan struktur dan masa otot seseorang.

\section{Simpulan}

Kejadian detraining memiliki hubungan yang signifikan terhadap tingkat daya ledak otot tungkai Atlet UKM Karate Universitas Negeri Malang. Hal tersebut disebabkan salah satunya karena kurangnya aktivitas fisik selama pandemi Covid-19. Perubahan gaya hidup dengan kurangnya aktivitas tidak aktif dan asupan gizi yang tidak seimbang maka akan menyebabkan terjadinya detraining. Kejadian detraining pada seseorang dapat mempengaruhi sistem fisiologis tubuh terutama pada kecepatan atau speed dan kekuatan kualitas kontraksi otot yang akhirnya mempengaruhi daya ledak seseorang. Dengan demikian semakin tinggi tingkat detraining maka semakin memengaruhi penurunan tingkat daya ledak pada seseorang.

\section{Daftar Rujukan}

Arga, L. D. (2018). Hubungan Antara Daya Ledak Otot Tungkai, Kekuatan Otot Pinggang Dan Kelentukan Tungkai Dengan Kecepatan Tendangan Mawashi Geri Jodan Pada Siswa Putra Ekstra Kurikuler Beladiri Karate Smp Negeri 8 Kota Kediri Tahun 2018. Jurnal Simki Thesain, 34.

Guna, I. S., \& Wibowo, M. (2017). Pengaruh Theraband Terhadap Peningkatan Daya Ledak Tungkai Di Klub Futsal Fisio 8b Unisa Yogyakarta.

Haf \& Bompa, 0. T. (2009). Periodization:Theory and Methodology of Training. United States of America: Sheridan Books.

Hidayat, A. (2018). Pengaruh Daya Ledak Tungkai, Koordinasi Mata Kaki Dan Keseimbangan Terhadap Kemampuan Shooting Ke Gawang Pada Permainan Sepakbola Siswa Sma Negeri 14 Sinjai. Universitas Negeri Makassar.

Indrayana, B., \& Yuliawan, E. (2019). Penyuluhan Pentingnya Peningkatan Vo2max Guna Meningkatkan Kondisi Fisik Pemain Sepakbola Fortuna Fc Kecamatan Rantau Rasau. Jurnal Ilmiah Sport Coaching And Education, 3(1), 41-50.

Joo, C. H. (2018). The effects of short term detraining and retraining on physical fitness in elite soccer players. PloS one, 13(5), e0196212.

Lennon, J. T., Muscarella, M. E., Placella, S. A., \& Lehmkuhl, B. K. (2018). How, when, and where relic DNA affects microbial diversity. MBio, 9(3), e00637-18. 
Kusmirantini, S. Y. (2019). Hubungan Power Tungkai dengan Tendangan Mawashi Geri dan Ushiro MawashiGeri pada Cabang Olahraga Karate. Jurnal Terapan Ilmu Keolahragaan, 53-54.

Maliki, A. (2018). Alternatif Alat Ukur Maximal Power Pukulan DAN Tendangan Berbasis Digital. Universitas Pendidikan Indonesia.

Mattioli, A. V., Puviani, M. B., Nasi, M., \& Farinetti, A. (2020). COVID-19 pandemic: the effects of quarantine on cardiovascular risk. European journal of clinical nutrition, 74(6), 852-855.

Mujika, I., \& Padilla, S. (2003). Physiological and performance consequences of training cessation in athletes: detraining. Rehabilitation of sports injuries: Scientific basis, 117.

Mujika, I., \& Padilla, S. (2000). Detraining: loss of training-induced physiological and performance adaptations. Part I. Sports Medicine, 30(2), 79-87.

Tran, T. T., Lundgren, L., Secomb, J., Farley, O. R., Haff, G. G., Nimphius, S., ... \& Sheppard, J. M. (2017). Effect of four weeks detraining on strength, power, and sensorimotor ability of adolescent surfers. The Open Sports Sciences Journal, 10(1).

Tosepu, R., Gunawan, J., Effendy, D. S., Lestari, H., Bahar, H., \& Asfian, P. (2020). Correlation between weather and Covid-19 pandemic in Jakarta, Indonesia. Science of the total environment, 725, 138436.

Zheng, X., Chen, J., Guo, Y., Xiong, Q., Hu, Y., Shi, S., \& Yu, Q. (2020). The buffer effect of physical activity: Why does parental marital satisfaction affect adolescents' problematic Internet use. Addictive behaviors reports, 11, 100271. 